\title{
A SHORT-FACED BEAR from Ice Age Deposits at Lebret, Saskatchewan
}

\author{
BY C. R. HARINGTON*
}

\section{Introduction}

In 1937, W. H. Rand and P. H. Stokes of Winnipeg collected some vertebrate fossils from an excavation in ice age (Pleistocene) gravels at Lebret. Of 16 fossils which they deposited in what is now the Manitoba Museum of Man and Nature $(\mathrm{MMMN}), 12$ are bison and three are mammoth. The last, and perhaps most interesting of the specimens, is a fragment of the mandible of a bear. An entry in the MMMN accession book indicates that this specimen had been examined and identified by the well known paleontologist C. M. Sternberg as a "bear's lower jaw."

What is the exact nature of the fossil, what kind of bear does it represent, how old is it? These are some of the questions I wished to answer when Dr. G. E. Lammers allowed me to borrow the fossil.

\section{Description and Identification}

The specimen (MMMN V186; Fig. 1) is a posterior fragment of the left mandible of a large bear. It contains most of the third molar tooth and the socket for the second molar. The part of the jaw that rises behind the cheek teeth (coronoid process) is missing, and the posterior extremities (mandibular condyle and angular process) are slightly eroded. The mandible fragment is more massive than the same part of a recent Kodiak Bear with which it was compared, which gives an idea of its large size.

A peculiar and significant feature of the specimen is a pronounced, oblique ridge behind and below the third molar (Fig. 1) with depressions for muscle attachments on either side. Living North American bears have only a single

*National Museum of Natural Sciences,

National Museums of Canada, Ottawa, Canada depression (masseteric fossa) where the cheek muscles are attached to the back of the mandible. This narrowed down the identification to an American subfamily of bears including Plionarctos (upper Pliocene age), Tremarctos (the Spectacled Bear of the Andes, and the only living member of this subfamily Pleistocene to Recent in age), and Arctodus of Pleistocene age. ${ }^{4}$

Measurements available on V186 (Table 1) show that the Lebret fossil lies beyond the known size of Spectacled Bears (Tremarctos), and is closest to that of the Short-faced Bear (Arctodus). In addition, the shape of the forward muscle attachment depression, the subtriangular shape of the third molar, and the basal breadth of the jaw where it rises behind the third molar are similar to those features in the Short-faced Bear. ${ }^{\text {? }}$

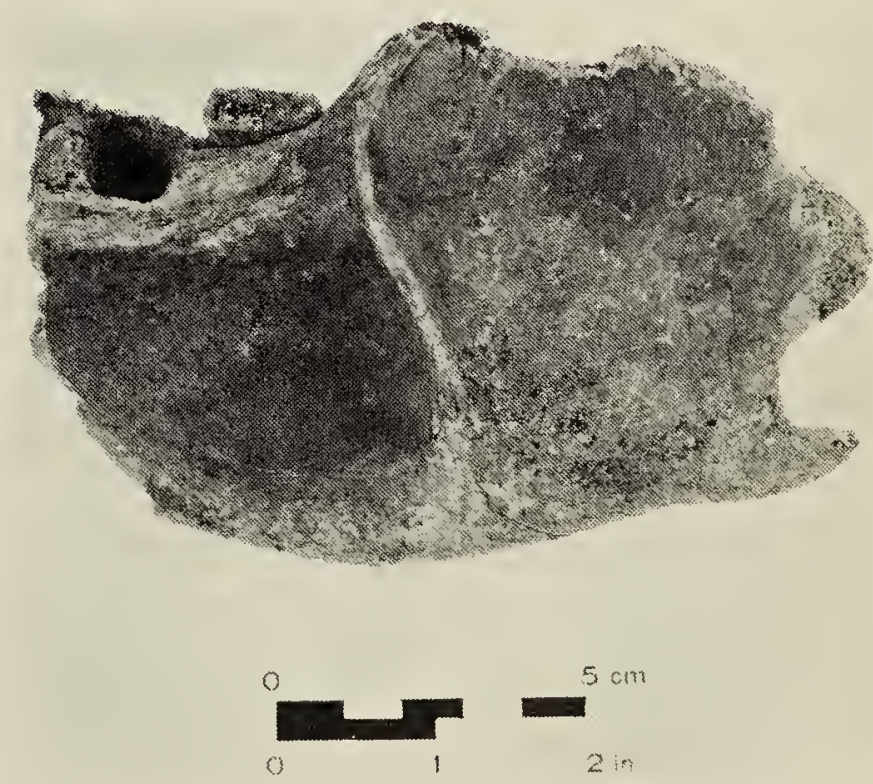

Fig. 1 - Left side view, Giant Short-faced Bear (Arctodus simus) mandible fragment containing $\mathrm{M}_{3}$ (MMMN V186) from Lebret, Saskatchewan. Note the partial socket for $M_{2}$ to the left of $M_{33}$. The oblique ridge dividing the premasseteric fossa from the masseteric fossa is characteristic of the Tremarctine bears such as Arctodus. 


\section{TABLE 1}

Measurements of the Lebret specimen (MMMN V186) compared to the giant short-faced bear (Arctodus simus), the eastern short-faced bear (A. pristinus), the North American spectacled bear (Tremarctos floridanus) and the spectacled bear (T. ornatus).

*1 - Length of $M_{3 .} 2$ - Width of $M_{3 .} 3$ - Depth of mandible below centre of $M_{3.4}-$ Minimum length, centre of $\mathrm{M}_{3}$ to notch between condyle and angular process. 5 - Anteroposterior diameter at base of coronoid process.

** Approximate measurements from scaled figure (Kurten 1967, Fig. 23).

Specimens

Arctodus simus MMMN V186

Lebret, Saskatchewan.

Pleistocene

$A$. simus UMMP V26368

Meade County, Kansas.

Pleistocene

A. simus $\mathrm{F}: \mathrm{AM} 25531$

Hay Springs, Nebraska

Pleistocene

A. simus ${ }^{5}$

Mean

Range

Number of specimens

A. pristinus $^{5}$

Mean

Range

Number of specimens

Tremarctos floridanus ${ }^{4}$

Mean

Range

Number of specimens

T. ornatus ${ }^{4}$

Mean

Range

Number of specimens
1

20.6

20.0

23.5

21.3

19.0-24.2

20

21.3

20.4-22.5

7

16.3

14.6-18.5

17

13.4

10.8-16.7

27

\section{Measurements (mm)*}

$2 \quad 3$

4

$18.1 \quad 63.8$

88.2

$\begin{array}{lll}16.8 & 67.5 & 104.3\end{array}$

$18.6 \quad 79.5^{* *} \quad 115.0 * *$

$97.0 * *$

17.1

15.0-19.1

20

16.5

$16.0-17.0$

7

12.3

11.6-13.9

17

10.2

8.7-12.5

27
Two North American species of Arctodus are recognized: Arctodus pristinus, which I will call the Eastern Short-faced Bear and Arctodus simus, the Giant Short-faced Bear." The first is relatively lightly built with small teeth and slender limbs. Its face is comparatively long with cheek teeth that seem small for the jaws. The second bear has a shorter face, and larger cheek teeth in deeper heavier jaws. The fossil is best referred to the Giant Short-faced Bear, considering the dimensions of the third molar tooth. The relative shallowness of the mandible (which approximates that of a Giant Short-faced Bear's mandible from the last interglacial (Sangamon) deposits in Kansas) suggests that the Lebret fossil represents a medium-sized individual, perhaps a female. ${ }^{25}$

Others reasons for considering that the Lebret specimen represents the Giant Short-faced Bear are: (1) the larger species is known to have lived during the Sangamon-Wisconsin period, while, so far, Eastern Short-faced Bear remains predate that period:5 (2) apparently the 


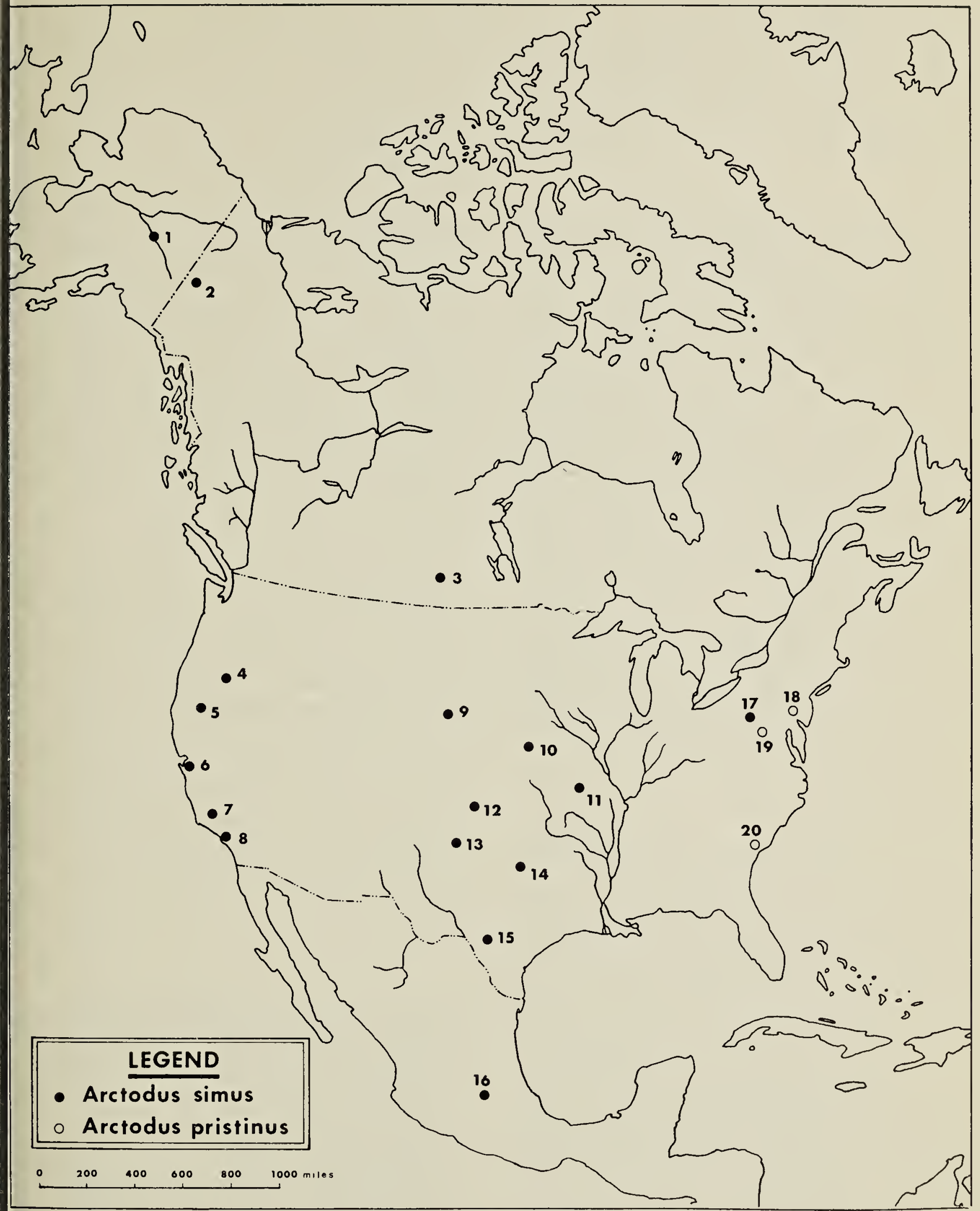

Fig. 2 - Some Pleistocene Short-faced Bear (Arctodus) localities in North America (most localities from B. Kurten )." Dots represent one or more specimens. Locality data: 1. Fairbanks area, Alaska. 2. Dawson City area, Yukon Territory. 3. Lebret, Saskatchewan. 4. Fossil Lake, Oregon. 5. Potter Creek Cave, California. 6. Irvington, California. 7. McKittrick, California. 8. Rancho La Brea (Los Angeles), California. 9. Hay Springs, Nebraska. 10. Cass County, Nebraska. 11. Carroll Cave and Perkins Cave, Camden County: Bat Cave, Pulaski County, Missouri. 12. Jinglebob locality, Meade County, Kansas. 13. Rock Creek, Texas. 14. Hill-Schuler locality, Denton County, Texas. 15. Friesenhaln Cave, Texas. 16. Tequixquiac, Mexico. 17. Frankstown Cave, Pennsylvania. 18. Port Kennedy Cave, Pennsylvania. 19. Cumberland Cave, Maryland. 20. Ashley River locality, North Carolina. 
Eastern Short-faced Bear was confined to the Atlantic coastal region of North America, while the Giant Short-faced Bear occupied the central and western parts of North America during the ice age (Fig. 2).

\section{Age}

An interesting feature of the specimen is its rust colour, due to staining by iron in the ground water. Its outer surface shows traces of a dark filigree pattern ("pyrolusite"), also due to mineral staining. In this respect it closely resembles vertebrate fossils from the Fort Qu'Appelle locality, which are thought to be of last interglacial (Sangamon) age. ${ }^{3}$ Lebret is 4 miles east, across the valley, from Fort Qu'Appelle. This evidence suggests to me that the mandible fragment is of Sangamon interglacial, or at the latest, of Wisconsin interstadial* age.

Sediment adhering to the fossil indicates that it came from a sandy gravel layer - probably an outwash deposit laid down near the close of the previously mentioned interglacial or interstadial.'

\section{Conclusion}

This is the second report of a Shortfaced Bear from ice age deposits in Canada. The first specimen, a nearly complete cranium (NMC 7438) was found near Dawson City, Yukon Territory, in 1909. ${ }^{6}$ It exceeds in size all other known skulls of the Giant Shortfaced Bear, and is probably of late Pleistocene age. The Lebret specimen is interesting because it shows that the same species also occupied what is now southern Saskatchewan during that period - probably about 100,000 years ago, or perhaps less.

The map (Fig. 2) indicates that the Giant Short-faced Bear occupied higher, well-drained grasslands in central and western North America during the ice age, while the Eastern Short-faced Bear preferred more heavily wooded regions near the Atlantic coast.

\footnotetext{
* A relatively brief, warm interval occuring in a glacial period. Cooler and of shorter duration than an interglacial, such as the present.
}

B. Kurtén considers the Giant Shortfaced Bear to have been a predominantly carnivorous species, and by far the most powerful predator in the ice age of North America." It may have preyed on large herbivores such as bison, deer, horses, and ground sloths (see cover). Bison and mammoths were among its contemporaries in southern Saskatchewan during the late Pleistocene.

The Giant Short-faced Bear became extinct toward the close of the Wisconsin glaciation some 10,000 years ago, perhaps partly because of the earlier extinction of some of its herbivorous prey species, and partly because of the increased competition with Brown Bears (Ursus arctos) which had entered North America from Eurasia.

\section{Acknowledgments}

I am grateful to: Dr. George E. Lammers (Manitoba Museum of Man and Nature) for lending me the specimen and for reading a draft of the manuscript; Dr. Claude E. Hibbard (University of Michigan) for supplying comparative measurements of a Shortfaced Bear mandible from Kansas; $\mathrm{Mr}$. G. Anderson (National Museums of Canada) for the photograph; and $\mathrm{Mr}$. C. Douglas (National Museums of Canada) for the map.

'Christiansen, E. A. 1972. Stratigraphy of the Fort Qu'Appelle vertebrate fossil locality, Saskatchewan. Can. Jour. Earth Sci. 9(2): 212-218.

${ }^{2}$ Hibbard, C. W. 1955. The Jinglebob interglacial (Sangamon?) fauna from Kansas and its climatic significance. Univ. Michigan Mus. Paleontol. Contr. 12(10): 179-228.

${ }^{3}$ Khan, E. 1970. Biostratigraphy and palaeontology of a Sangamon deposit at Fort Qu'Appelle, Saskatchewan. Nat. Mus. Can. Publ. Palaeontol. No. 5: $1-82$.

'Kurtén, B. 1966. Pleistocene bears of North America. 1. Genus Tremarctos, spectac'ed bears. Acta. Zool. Fennica 1 15:1-120.

"Kurtén. B. 1967. Pleistocene bears of North America. 2. Genus Arctodus, short-faced bears. Acta. Zool. Fennica 1 17:1-60.

"Lambe, L. M. 1911. On Arctotherium from the Pleistocene of Yukon. Ottawa Nat. 25 (2): 21-26.

${ }^{7}$ Merriam, J. C. and C. Stock. 1925. Relationships and structure of the short-faced bear, Arctotherium, from the Pleistocene of California. Carnegie Inst. Washington Contrib. Palacontol. Publ. 347 (1): 1-35. 